\begin{tabular}{|c|c|c|c|c|c|c|c|c|}
\hline $\begin{array}{c}\text { Max. } \\
\text { Vari }\end{array}$ & & $\begin{array}{l}\text { Taur } \\
\text { Min. } \\
\text { rap }\end{array}$ & & $\begin{array}{r}\text { Max. } \\
\text { Var } \\
\alpha= \\
\delta=\end{array}$ & $\begin{array}{l}S \mathrm{Ca} \\
3,0 \mathrm{M} \\
\text { ciation } \\
=8^{\mathrm{h}} \\
=+\end{array}$ & $\begin{array}{l}\text { ancri } \\
\text { In. } 10,5 \\
\text { n rapid } \\
35^{m} 56^{3} \\
19^{\circ} 32^{\prime}\end{array}$ & $\begin{array}{r}\eta \mathbf{A q}_{i} \\
\text { Max. } 3,6 \\
\text { Increas }\end{array}$ & $\begin{array}{l}\text { ilae } \\
\text { Min. } 4,4 \\
\text { gig } 2^{29^{2}}\end{array}$ \\
\hline Jan. & 1 & $6^{\mathrm{h}}$ & $8^{m}$ & Jan. & 16 & $15^{\mathrm{b}} 19^{\mathrm{m}}$ & Febr. 15 & $18^{\mathrm{h}} 12^{\mathrm{m}}$ \\
\hline & 5 & 5 & 0 & Febr. & 4 & 1433 & March23 & 1522 \\
\hline March & & 8 & 40 & & 23 & 1347 & April 28 & 1233 \\
\hline & 21 & 7 & 32 & March & 114 & 131 & June 10 & 1357 \\
\hline Aug. & 6 & 15 & 59 & April & 2 & 1215 & July 16 & 117 \\
\hline & 10 & 14 & 51 & & 21 & 1128 & 23 & 1522 \\
\hline & 14 & 13 & 43 & May & 10 & 1042 & Aug. 21 & 818 \\
\hline & 18 & 12 & 36 & & 29 & $\begin{array}{ll}9 & 56\end{array}$ & 28 & 1232 \\
\hline & 22 & 11 & 28 & June & 17 . & 910 & Octbr. 3 & $\begin{array}{ll}9 & 42\end{array}$ \\
\hline Oct. & 24 & 17 & 23 & Sept. & 29 & 1656 & Novbr. 8 & $\begin{array}{ll}653\end{array}$ \\
\hline & 28 & 16 & 15 & Oct. & 18 & 1610 & Dec. 14 & 43 \\
\hline Nor. & 1 & 15 & 7 & Nov. & 6 & 1524 & & \\
\hline & 5 & 14 & 0 & & 25 & 1437 & ?Ger & inorum \\
\hline & 9 & 12 & 52 & Dec. & 14 & 1351 & $\begin{array}{r}\text { Mäx. 3, } \\
\text { Increa }\end{array}$ & $\begin{array}{l}\operatorname{Min} .4,5 \\
5^{d} 6^{\mathbf{k}}\end{array}$ \\
\hline & $\begin{array}{l}13 \\
17\end{array}$ & $\begin{array}{l}11 \\
10\end{array}$ & $\begin{array}{l}44 \\
36\end{array}$ & & & & Ja0. 9 & $\overline{5^{\mathrm{h}} 24^{\mathrm{m}}}$ \\
\hline & 21 & & 28 & & & & 19 & $\begin{array}{ll}9 & 12\end{array}$ \\
\hline & 25 & & 21 & & & & 29 & 130 \\
\hline & 29 & & 13 & & & & March21 & 80 \\
\hline Dec. & 3 & 6 & 5 & & & & 31 & 1148 \\
\hline & 7 & & 57 & & & & Oet. 10 & 120 \\
\hline & & & & & & & 20 & 1548 \\
\hline & & & & & & & Dec. 10 & 1048 \\
\hline & & & & & & & 20 & 1436 \\
\hline & & & & & & & 30 & 1824 \\
\hline
\end{tabular}

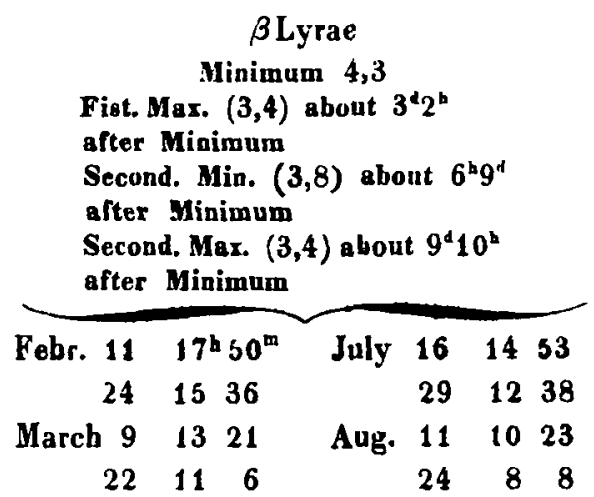

So many sources of interruption bave of late cooperated to derange my plans and interfere with steady work, that ever this little promised annual ephemeris has been most unwillingly delayed until five month after its due time of publication. I am happy to say however, that such delay is not likely to happen again, as in the position which I have now the honor to fill, in Dr. Lee's Observatory, the Variable Stars are to he special objects of observation and investigation. -

With few exceptions the same elements have been employed in preparing this as in the last years ephemeris. Where no authority is given, the times of maxima are not to be regarded as predictions, but merely as indications as to when a search will best contribute to our knowledge of such star. - Even a record of invisibility at such a time is of great value, as it negatives the assumed period, and thereby clears away an error from a future ephemeris. - For the short-period Variables (all of whicb, exceqt $\lambda$ Tauri, are from Prof. Argelander's elements) those minina only are tabulated which occur when the sun is considerably below and the star at least ten degrees above the horizon. -

I am again indebted to Mr. Baxendell for having obligingly comnunicated the latest particulars respecting $\lambda$ Tauri, 13 Lyrae, and $\boldsymbol{R}$ and $\boldsymbol{S}$ Herculie, from his own observations. - Similar assistance, from whatever quarter it nay he afforded, will always be nost acceptable and gratefully received.

Hartwell Observatory, 1859 April 11.

Norman Pogson.

\title{
Entdeckung eines Cometen.
}

\section{Schreiben des Herrn Trettenero an den Herausgeber.}

I giorno 2 Aprile corrente Sigør. Tempel scopi a Venezia una piccola Cometa nell' Orsa Minora, e non avendo a propria disposizione strumenti di misura ne chetermino prossimamente la posizione coll'atlante di Harding. Essa ora la sequenta: ad $8^{\mathrm{h}} \alpha=14^{\mathrm{h}} 30^{\circ} d=71^{\circ}$.

Jeri sera ne abbiamo qui determinata la posizione al Micrometro Circolare di un Cannocchiale libero. Ecco il risultato :

Padova, 1859 Aprile 8.

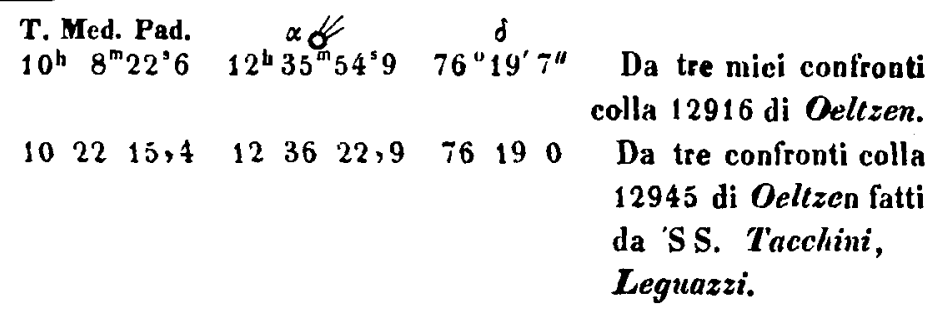
colla 12916 di Oeltzen.

$\begin{array}{lllllllll}10 & 22 & 15,4 & 12 & 36 & 22,9 & 76 & 19 & 0\end{array}$ Da tre confronti colla 12945 di Oeltzen fatti da 'S S. Tracchini, Leguazzi.

Nella nostra piccola Parallattica la Cometa è invisibile; e la Parallattica maggiore ricevuta nello scorso anno non potà essere ancora montata.

Virgilio Trettenero. 